\title{
Impact of Oil Revenue Spending on Income Distribution: the Case of Azerbaijan
}

Received: 06.08.2021

Available online: 28.12 .2021

Hamza Khalilov*, Ramil Huseyn ${ }^{* *}$

\section{Abstract}

This paper examines the impact of the oil factor on income distributionin a resource-rich country, Azerbaijan. Since the early 2000 s, the rapid increasein oil revenueshas been used for the economic and social development in the country. The increased revenues from oil sales has led to a sharp increase in the share of the top $10 \%$ of the population in total income, the stabilization of the share of the lowest $10 \%$, and a significant decline in the share of the middle layer. The widespread use of oil revenues has played a leading role in the formation of new structural features in social stratification. In addition to the sharp decline in extreme poverty in the country, the layer with a higher income has emerged. At the same time, increasing oil revenues has not given a strong impetusto the formation of a prosperous middle layer. This paper also demonstrates that the solution of the income inequality problem isrelated to improving the quality of institutions, enhancement strategies for the use of oil revenues in the short and long terms, as well as ensuring the consistent implementation of an active diversification policy.

Keywords: oil factor, oil revenues, population incomes, income inequality, Gini coefficient, social stratification.

JEL : Q33, P24, P36, D63, D64

\section{Introduction}

$\Delta$ zerbaijan is among the former Soviet countries where oil plays an important role in the economy. In the early 2000s, in the wake of the transition crisis, the oil and gas sector accounted for $1 / 4$ of the GDP. Later, due to the improved conjuncture in the hydrocarbon resources market and the start of the next mining boom ${ }^{1}$ since 2005 , revenues from oil sales have become an important source offinancing the economic and social development. Revenues from the oil sector accounted for $2 / 3$ of the public budget in the period of 2005-2013. In some years this figure was over $70 \%$.

Along with the increase of oil production, the stimulation of investment and consumption as a result of the spending of funds from the sale of oil has led to high growth rates in the economy. At the same time, the oil sector has gained a dominant position in the country's

\footnotetext{
Azerbaijan University of Architecture and Construction, Faculty of Economics, Baku

" Chairman of the Scientific Seminar at the Azerbaijan State Economic University (UNEC), Baku, Azerbaijan

${ }^{1}$ As a result of the development of the country's large hydrocarbon reserves in the Caspian Sea sector, the increase volume of oil and gas production in Azerbaijan between 2005 and 2010 has exceeded 3.0 times (SSCAR, 2018, p.459).
} 


\section{Articles}

economy. Even after the end of the rapid increase in production, the oil factor continues to play an important role in determining the overall development dynamics.

Increasing the competitiveness of the country's economy and welfare has been ensured through the use of large oil revenues. According to the Global Competitiveness Report published by World Economic Forum for 2019, Azerbaijan ranked 58th among 141 countries.

The widespread spending of oil revenues has accelerated the growth of household incomes. In the 2000s, the Republic of Azerbaijan was one of the world's leading countries in terms of population growth and household consumption. At the same time, the widespread use of oil resources has been accompanied by significant changes in the distribution of income. Under such conditions, new features have emerged in the social stratification of the population.

We are investigating the effect mechanism of the dynamics of the portion of the proceeds from the sale of hydrocarbon resources in the oil economy for economic and social development and the distribution of income.

The following points can be attributed to the contribution of the article to the study of problems: the article identifies the nature of the relationship between changes in oil revenue spending and the level of income inequality; The structural features of the impact of large-scale spending of oil revenues on the distribution of income among different groups of the population and the factors that determine them are explained; To provide considerations on the main medium and long term priorities for reducing income inequality under the condition of the dominance of the oil sector in the economy.

\section{Literature review}

As Michael L. Ross(2006) notes, despite some claims to the contrary, in fact surprisingly little is known about the links between mineral wealth and vertical inequality. We can say that today there is a small number of studies directly devoted to the study of the relationship of oil revenues to the distribution of income. In the available literature sources there are two different approaches to assessing the impact of oil on income distribution.

In one case, the oil factor has been shown to act as a means of increasing income inequality. Lukke et al.(2006), who studied the impact of hydrocarbon resources on inequality using the example of the gas boom in Bolivia, concluded that increased production led to increased inequality and poverty in the country. Muhammad Ali Moradi's (2009) study also states that the influence of the oil factor on inequality is in this direction. The study based on data from the Islamic Republic of Iran for 1968-2005 showed that the effect of real oil revenues on the Gini coefficient was negative, but the corresponding indicator did not receive a significant estimate.

In another case, researchers show that the oil factor can have a positive effect on reducing income inequality. PO Oviasuyi and AE Omoregie's (2016) study the relationship between oil export revenues in Nigeria and income inequality based on data for 19902014. Using the ARDL model shows that oil revenues in this country have a positive effect on reducing income inequality. At the same time, however, high levels of corruption in the oil sector weakened this effect, leading to a widening gap between rich and poor. In fact, this is a confirmation of the opinion of observers that in countries rich in natural resources, mineral rent, with weak institutions, this fact will lead to an increase in income 


\section{Articles}

inequality, which is also pointed out by Michael L. Ross (2006) ${ }^{2}$.

In the economic literature, attention is also drawn to the fact that the influence of the oil factor on the distribution of income is associated with the structural features of the country's economy. Edvar, Hugo Mol, Sergio Rodriguez, Peter K. Schott (1999) show that the influence of the wealth of natural resources, including oil, on the level of inequality is associated with the position of individual sectors in the structure of the economy.

The issue of the relationship between oil revenues and the distribution of income in Azerbaijan is considered by Gulaliyev (2020). The model that is used by the author to study the relationship between inequality in income distribution and some macroeconomic indicators, and in which the Gini coefficient was taken as the dependent variable, includes income from natural resources (mineral products) as one of the explanatory variables.

Furthermore, the concluding section of the article notes that the level of inequality in income distribution in Azerbaijan is not related to oil revenues. At the same time, it draws attention to the following aspects of considering this issue in the article. First, the content of the indicator "income from natural resources (mineral products)" was not clarified, and the sources of information on this were not specified. Second, the article does not present the results of the regression analysis in this respect.
Impact of Oil Revenue Spending on Income Distribution:

the Case of Azerbaijan

\section{Methodology and data}

The income obtained from the sale of hydrocarbon raw materials that is spent on economic and social development in the oil economyis seen as an exogenous factor of development. Such an approach stems from the characteristics of the formation of these revenues and their impact on the national economy. At the same time, the impact of the use of oil revenues on population income is multidimensional. It should be taken into account that oil revenues, in addition to their direction by the state for the growth of population income, affects these incomes also through the growth of economic activity and ensuring macroeconomic stability. Considering that the study is carried out on the basis of the example of a single country's economy, the relationship between the use of petroleum resources and the generation of population income is investigated in terms of the establishment of a dynamic series and analysis of their interdependence using correlation-regression methods.

As the main indicator of inequality, the Gini coefficient is used, which is based on the distribution of the nominal population incomes. To assess income inequality, it may also be advisable to use a differentiation indicator based on national income, which is used in the World Inequality Report prepared by the World Inequality Laboratory. However, in the report, this indicator is still presented for the limited number of countries and mainly covers large economies. The Republic of Azerbaijan is not among these countries.

However, we use the World Inequality Laboratory approach in the distribution of

${ }^{2}$ Michael L. Ross also draws attention to the growth potential of the public sector, which will lead to lower wages and increased inequality in the conditions of resource wealth. At the same time, he emphasizes that the lack of relevant data and analyzes makes it impossible to determine which scenario is more likely (Michael L. Ross, 2006). 


\section{Articles}

population groups (separation of the first $1 \%$, the first $10 \%$, the middle $40 \%$, the lowest $50 \%$ and the lowest $10 \%$ groups) in order to provide a wider perspective on the issue when assessing income inequality.

Official statistics in Azerbaijan do not publish the Gini Index. However, it is possible to calculate this indicator based on data of distribution of the average monthly income per capita.

Wherein there are two important aspects to consider.

First, the official statistics use different ranges when selecting income groups of distribution of income per capita by years. In this regard, it is not possible to determine the share of the top $1 \%$ in the population incomes in all cases based on the data provided.

Second, the absolute value of the final amount shown in the income gradient is relatively small. (This figure is AZN $130-160$ in 2005-2007, AZN 280-300 in 2008-2016, and AZN 525 in 2017 that are equivalent tothe current rate of USD 150, USD 350 and USD 300 , respectively). In this case, the amount of total income calculated within this gradation turns out to be significantly lower than the actual amount of income of the population.

In connection with the above, it is necessary to consider the amount corresponding to that difference as the income of final decile. Since the corresponding distribution given by official statistics applies to the entire population of the country, it should also cover the weight of income ${ }^{3}$.

When using this rule, in order to comply with the consistency of the basic data, the indicator calculated on the basis of the methodology applied in the year to which the data on the distribution of income per capita belongs is taken as the total volume of income.

Oil revenues used for economic and social development purposes include transfers from the Azerbaijani State Oil Fund to the state budget in the relevant years and investments in other local investment projects, income tax under the oil and gas production distribution agreement, payments to the state budget of the oil and gas companies and wages paid to the employees.

\section{Income Inequality: The "Structure- forming" Role of Oil Revenue}

The rise in prices in the hydrocarbon markets since the early 2000 s, as well as the rapid growth in oil production in Azerbaijan, increased revenues from the oil sector and, as a result, a large-scale expansion in the use of oil money for economic and social development, was accompanied also by a steady increase in nominal income population. Also, in Azerbaijan, poverty declined significantly in both rural and urban areas. With the decline in the used oil revenues between 2014-2017, the nominal incomes per capita have declined significantly ${ }^{4}$ (Table 1).

\footnotetext{
${ }^{3}$ The value of the Gini coefficient, calculated with the adoption as the border of the last absolute figure on gradation of income applied in the official statistics of Azerbaijan it turns out too small, and is significantly different from the corresponding indicators on other countries. This value corresponds to the Gini Coefficient indicator for Azerbaijan presented in UNDP reports. According to given data UNDP by countries, the Gini Ratio is $16.6 \%$ in Azerbaijan, which is 8.4 percentage points lower than the corresponding figure on Ukraine, 8.8 percentage points Slovenia and 9 percentage points lower than Iceland (this is countries with the lowest Gini coefficient). Azerbaijan is the only country where the value of the Gini coefficient is less than $25 \%$. (UNDP, 2018). In this case, in fact, there is some discrepancy, and the approach we propose is aimed at eliminating it.

${ }^{4}$ In the Republic of Azerbaijan the corresponding per capita distribution is given by volume of consumption for the period from to the previous 2003.
} 
Table 1. Changes in the used oil revenue, nominal income and Gini coefficients for the period 2003-2017

\begin{tabular}{|c|c|c|c|c|c|c|c|c|c|c|c|c|c|c|c|}
\hline & 2003 & 2004 & 2005 & 2006 & 2007 & 2008 & 2009 & 2010 & 2011 & 2012 & 2013 & 2014 & 2015 & 2016 & 2017 \\
\hline \multicolumn{16}{|c|}{ Amount of used oil revunue per capita } \\
\hline $\begin{array}{l}\text {-AZN (NGH) } \\
\text { - US dollars } \\
\text { (UOR) }\end{array}$ & $\begin{array}{l}77 \\
78\end{array}$ & $\begin{array}{l}88 \\
90\end{array}$ & $\begin{array}{l}120 \\
122\end{array}$ & $\begin{array}{l}368 \\
372\end{array}$ & $\begin{array}{l}518 \\
603\end{array}$ & $\begin{array}{c}940 \\
1145\end{array}$ & $\begin{array}{l}774 \\
962\end{array}$ & $\begin{array}{c}923 \\
1150\end{array}$ & $\begin{array}{l}1376 \\
1749\end{array}$ & $\begin{array}{l}1503 \\
1909\end{array}$ & $\begin{array}{l}1663 \\
2119\end{array}$ & $\begin{array}{l}1438 \\
1833\end{array}$ & $\begin{array}{l}1205 \\
1174\end{array}$ & $\begin{array}{l}1114 \\
698\end{array}$ & $\begin{array}{l}975 \\
566\end{array}$ \\
\hline $\begin{array}{l}\text { - Index of change } \\
\text { in the previous } \\
\text { year (ORI) }\end{array}$ & & $\begin{array}{c}1.1431 \\
1.154\end{array}$ & $\begin{array}{l}1.364 \\
1.356\end{array}$ & $\begin{array}{l}3.067 \\
3.049\end{array}$ & $\begin{array}{l}1.408 \\
1.621\end{array}$ & $\begin{array}{c}1.815 \\
1.9\end{array}$ & $\begin{array}{c}0.823 \\
0.84\end{array}$ & $\begin{array}{l}1.192 \\
1.106\end{array}$ & $\begin{array}{l}1.491 \\
1.521\end{array}$ & $\begin{array}{l}1.092 \\
1.091\end{array}$ & $\begin{array}{c}1.106 \\
1.11\end{array}$ & $\begin{array}{l}0.864 \\
0.865\end{array}$ & $\begin{array}{c}0.838 \\
0.64\end{array}$ & $\begin{array}{l}0.924 \\
0.595\end{array}$ & $\begin{array}{l}0.875 \\
0.811\end{array}$ \\
\hline \multicolumn{16}{|c|}{ Nominal income per capita } \\
\hline -manat (NOIA) & 614 & 734 & 962 & 1201 & 1692 & 2378 & 2560 & 2866 & 3384 & 3789 & 4040 & 4192 & 4381 & 4710 & 5051 \\
\hline $\begin{array}{l}\text { - Index of change } \\
\text { in the previous } \\
\text { year (NOII) }\end{array}$ & & 1.196 & 1.311 & 1.25 & 1.41 & 1.383 & 1.092 & 1.122 & 1.180 & 1.121 & 1.066 & 1.036 & 1.046 & 1.077 & 1.072 \\
\hline Gini coefficient* & 0.282 & 0.327 & 0.372 & 0.346 & 0.399 & 0.444 & 0.402 & 0.398 & 0.436 & 0.429 & 0.43 & 0.429 & 0.428 & 0424 & 0.407 \\
\hline
\end{tabular}

Source: SOFAZ, 2019; SSCAR, 2018.

*Data on the Gini coefficient in the Republic of Azerbaijan is also provided by other resherchers. (Gulaliyev and et. 2018, pp.95-96) However, in our opinion, presented by Gulaliyev et al. (2018)the value of this indicator for 2005 and 2009-2016 is too high and cannot be assumed as real values.

In parallel with the changes in the oil revenue used, dynamic changes occurred in the value of the Gini coefficient on the distribution of income.

Correlation analysis shows that there is a significant correlation between the US dollar oil revenues used in Azerbaijan and the nominal income per capita as well as between the growth rates of these indicators (Table 2).
Such a situation allows us to say that in connection with the dominant position of the oil factor in the country's economy used revenue from these sector for economic and social development has been one of the major factors determining the level and dynamics of the population's income during the study period.

Table 2. Correlation matrix of the relationship between used oil revenues, population incomes and Gini coefficient

\begin{tabular}{|l|r|r|r|r|r|}
\hline & \multicolumn{1}{|c|}{ UOR } & \multicolumn{1}{c|}{ ORI } & \multicolumn{1}{c|}{ NOIA } & \multicolumn{1}{c|}{ NOII } & Gini coefficient \\
\hline UOR & 1 & & & & \\
\hline ORI & -0.147578426 & 1 & & & \\
\hline NOIA & 0.647686633 & -0.20865 & 1 & & \\
\hline NOII & -0.267230046 & 0.546021 & -0.49628 & 1 & \\
\hline Gini coefficient & 0.748935895 & 0.007043 & 0.753223 & 0.073692 & 1 \\
\hline
\end{tabular}

In addition, there is a strong correlation per capita spending of oil revenue. In this case, between the value of the Gini coefficient and $\mid$ the linear correlation coefficient was about 


\section{Articles}

0.749. Interestingly, the correlation of the Gini coefficient with the oil revenue growth rate was weak. In other words, changes in income inequality in each particular period are more likely to "react" to the amount of oil revenue used. In this context, the high absolute and relative volumes of used oil resources leads not only to a change in the total volume of income, but also due to various features in their direct and indirect influence on the formation of incomes of different groups of the population, leads to changes in inequality.
Dynamic changes in the volume of oil revenue used for economic and social development in the Republic of Azerbaijan in the 2000s was one of the major factors affecting the level of income inequality in the country. From a chronological point of view, it is possible to distinguish two stages in this area. In the first stage that covers 2003-2013, the value of the Gini coefficient increased as the volume of oil revenue spending increased. (Figure 1).

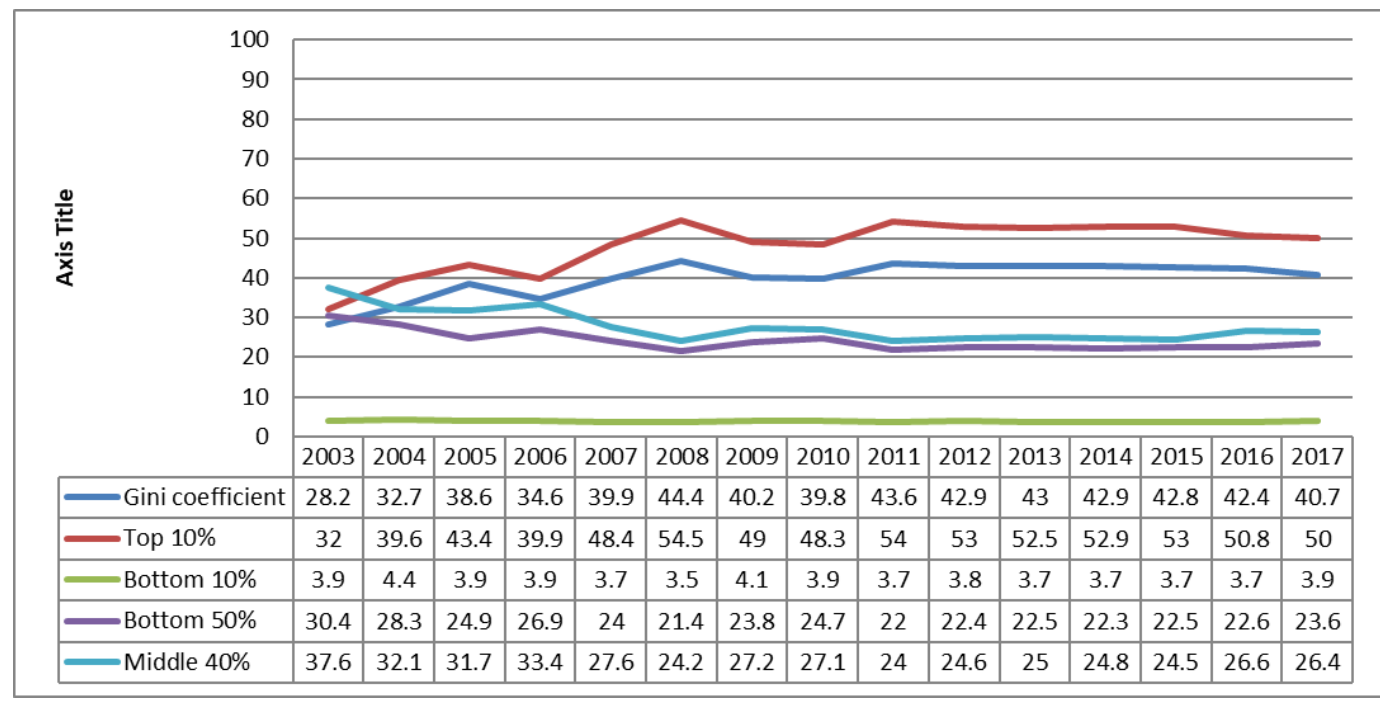

Figure 1. Indicators of the Gini coefficient and the share of income of the population groups for 2003-2017

From 2003 to 2013, the Gini coefficient increased from $28.2 \%$ to $43 \%$. In income distribution, the difference between the first and last deciles increased from 8.2 times to 14.2 times, and the difference between the first and last quintiles increased from 4.3 times to 7.5 times. The high rate of decline in oil revenues used during the second phase, 2014-2017, was accompanied by a slight decrease in the Gini coefficient.

In general, the trend of correlation between the amount of oil revenues used and the value of the Gini coefficient is more consistent with the logarithmic function (Figure 2). 


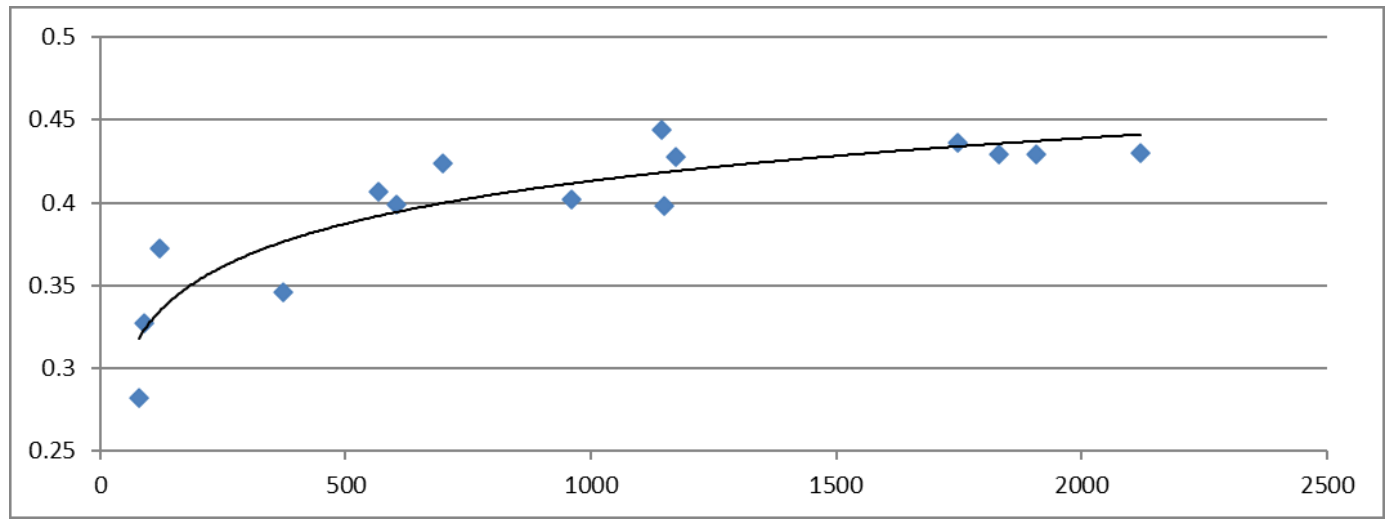

Figure 2. Change in used oil revenues and Gini coefficient

The rise in oil revenues to a certain level (per capita, approx. USD 1,000) is consistent with the rapid growth of the Gini coefficient. With subsequent increases in income levels, the coefficient has changed slightly in the appropriate direction. The fit of the curve shown in the diagram to the initial data flow is $80.1 \%$.

In regard to the above, in regression analysis of the relationship between the oil revenues used and the Gini coefficient, the first indicator is used in the decimal logarithmic expression. The model for the surveyed period is based on the following formula.

$$
G C=16.50625+8.279435 \operatorname{Ln} U O R+\varepsilon
$$

Here,

$C E$ - Gini Coefficient (in\%)

LnUOR - the value of per capita oil income usedin logarithmic expression

$\varepsilon$ - Model error

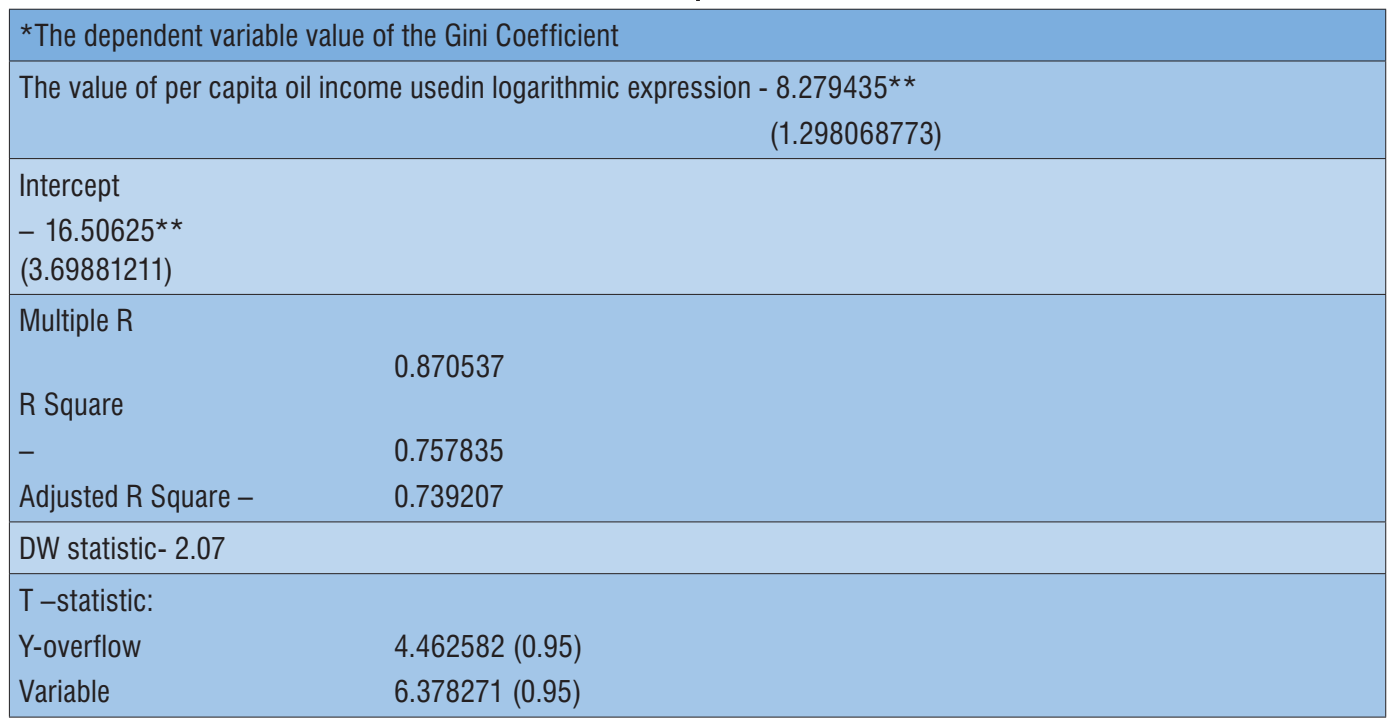

\footnotetext{
(...) indicates the standard error of the coefficient

* The indicator is expressed in percentages

** Indicators are accepted within the $95 \%$ confidence interval
} 


\section{Articles}

The results of the appropriate tests show that the model is reliable. ${ }^{5}$ Calculated values of the Gini coefficient for the model are shown in the graphic form as follows:

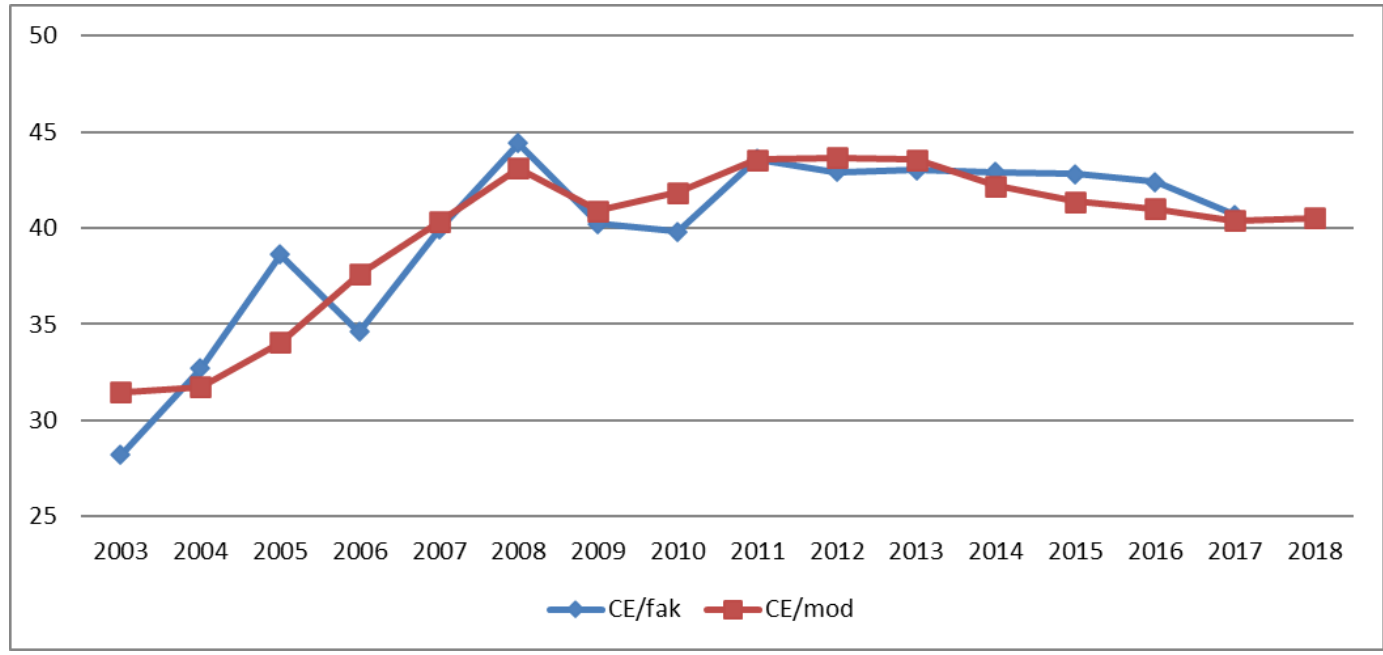

Figure 3. The model of the dependence of the Gini coefficient on the amount of used oil revenue per capita

The analysis of diagram 3 shows that according to the model, the values of the Gini coefficient at the end of the period are closer to the real indicators.

The main processes that gave the background in increase in income inequality during the increase in the volume of oil revenues used were a sharp increase in the share of incomes of the richest $10 \%$, the practically unchanged share of $10 \%$ with the lowest incomes, a significant decrease in the share of $40 \%$ with middle incomes and the share of $50 \%$ with low incomes. At the same time, the intensity of changes in these areas was slightly lower in 2011-2013 compared to 2003-2010. This is due to a decrease in the size of income differences between groups due to a decrease in the average annual growth rate compared to the previous period.

The peculiarities in changing the share of income for particular groups are closely linked to the different effects of oil revenues on them. The coefficient of elasticity of changes in the share and volume of incomes on $10 \%$ of the most high-income and $40 \%$ of the average income groups was high. For the group with the lowest income of $10 \%$ this indicator was negligible. (Table 3)

\footnotetext{
${ }^{5}$ The value of the regression coefficients for both factors is statistically insignificant when the GDP level (volume per capita in real terms) is included as the second factor in the regression model. This can be attributed, firstofall, to the strong interconnectedness of the factors included in the model due to the dependence of the Azerbaijani economy on the oil factor during the period under review. The linear correlation coefficient between GDP and used oil revenues per capita, according to data for the same period, was greater than 0.91 .
} 
Table 3. Indicators of changes in income by different groups of population

\begin{tabular}{|l|l|c|c|c|c|c|}
\hline & & \multicolumn{2}{|c|}{$\begin{array}{c}\text { Average annual growth } \\
\text { rate of income (\%) }\end{array}$} & $\begin{array}{c}\text { Share in total } \\
\text { income growth } \\
\text { (\%) }\end{array}$ & $\begin{array}{c}\text { The coefficients of elasticity } \\
\text { of the change in the share of } \\
\text { the groups of the amount of } \\
\text { oil income used. }\end{array}$ & $\begin{array}{c}\text { The coefficients of elasticity } \\
\text { of the change in the value } \\
\text { income of the groups of the } \\
\text { amount of oil income used. }\end{array}$ \\
\cline { 3 - 6 } 1 & Top 10 \% & 19.5 & -2.3 & 57 & 0.12 & 0.540 \\
\hline 2 & Bottom 10\% & 13.3 & 0.3 & 3.9 & -0.02 & 0.385 \\
\hline 3 & Bottom 50\% & 10.4 & 0.6 & 21.0 & -0.07 & 0.320 \\
\hline 4 & Middle 40\% & 9.2 & 0.7 & 21.9 & -0.11 & 0.293 \\
\hline
\end{tabular}

Source: Authors' calculations based on SSCAR data (SSCAR, 2019)

Under the condition of the increase of the oil revenue used, the growth rate for the $10 \%$ highest income group (mainly the top $1 \%$ ) was also the highest. At a much smaller rate, the incomes of those who belong to the first decile have increased. The smallest growth rate belongs to the middle income group of $40 \%$. The indicator of increase of the bottom $50 \%$ is in the middle between the indicated two groups. In general, the difference between the indicators was in the 2-fold range.

The characteristics formed by the dynamics of income inequality under the aforementioned features is also reflected in the Lorentz curve form for different years of the study period (Figure 4).The initial parts of the curves under consideration almost coincide.The curves under consideration almost coincide at the beginning (in the section corresponding to the first decimal). At the same time, the difference between the degree of curvature of the curves for 2013 and 2017 , compared to 2003 , is higher at the point corresponding to $90 \%$, while after this point the growth of the curves is sharper.

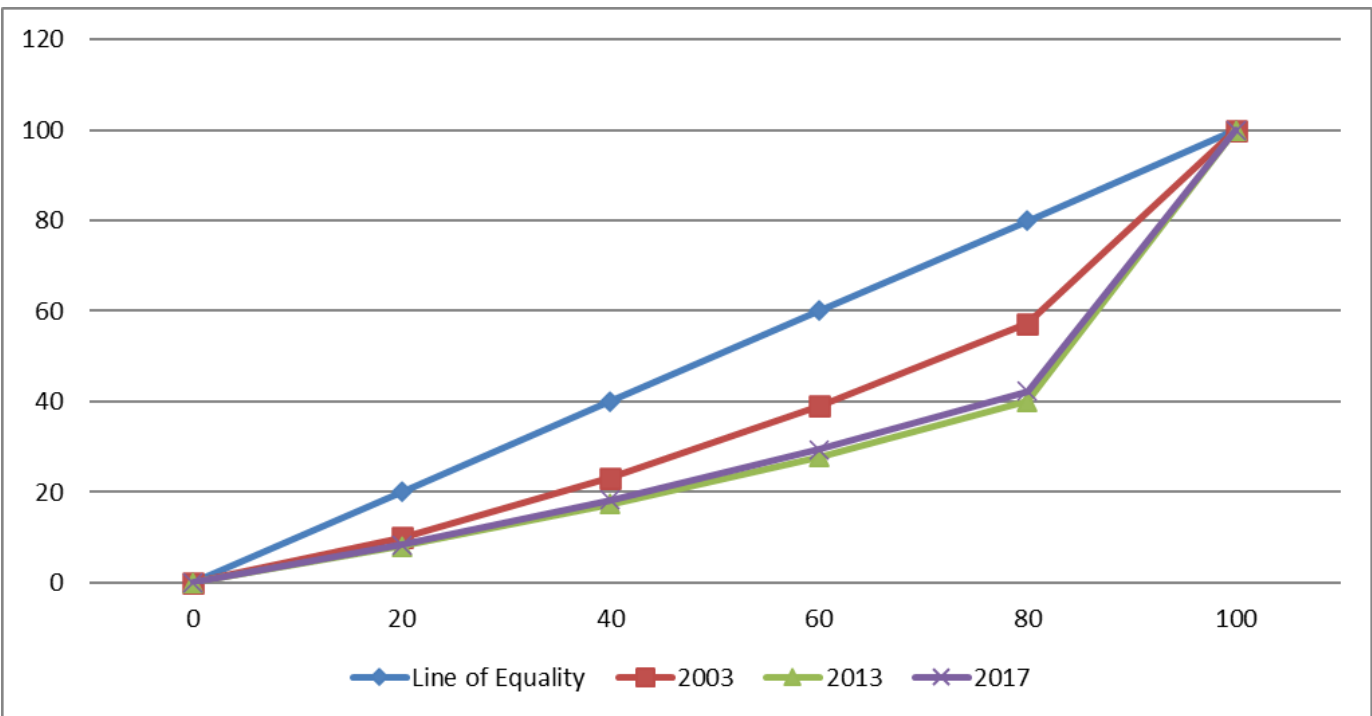

Figure 4. Lorentz curve for 2003, 2013 and 2017 in the Republic of Azerbaijan 


\section{Articles}

The specifics in changing the share of income in the respective groups are closely related to differences of infulenceof used oil revenues on income generation across different groups of the population.This is reflected in the comparison of income growth rates for the various groups under consideration (Table 3).

Higher income growth rates in the top $10 \%$ group were driven primarily by increased employment in the oil and gas sector and its service sector, and higher wage increase compared to other sectors under the conditions of extraction boom. The ratio of wages in the extractive sector to the average wage in the economy was 3.7 in 2003 and 4.3 in 2013 and the relative incomes of the latter have increased. At the same time, the expansion of the financial and credit sector with high wages, as well as the relatively high salaries of hired workers, stimulated the expansion of such sectors as construction and transportation. On the other hand, entrepreneurial income has grown at an accelerated pace (2/3 of the total increase in population incomes in 20032013 fell to the share of business income) due to the high inflow of large amounts of money into the economy. In the process, highincome activities have also expanded. In other words, the use of oil revenues has led directly or indirectly to the expansion of sectors with higher labor incomes.

It should be borne in mind that the increase in incomes in the last decile is mainly attributable to the share of the top $1 \%$. Its increase was $86.6 \%$ in $2003-2008$ and $81.4 \%$ in 2008-2017. With the expansion of oil revenues, the incomes of the top $1 \%$ in
Azerbaijan grew rapidly, with their share of the population's income rising from $23.9 \%$ in 2003 to $41.5 \%$ in 2017 . Such a situation can be connected, first of all, with the rapid growth of public investments, including budgetary investments, under the conditions of a wide use of oil revenues.

Lack of insufficient high level of the quality of institutions and transparency, lead to obtaining large income for some people involved in the use of these funds.This directs attention to the direct and indirect manifestations of the Voracity effect which is characteristic for cases of extraction booms ${ }^{6}$.

The Republic of Azerbaijan collects and manages oil revenues through the SOFAZ with a sovereign fund status, which operates in accordance with the required transparency requirements. Azerbaijan has joined the Extractive Industries Transparency Initiative. However, the use of a large amount of revenue from oil exports has also made it possible for small groups of people to absorb funds.The sharp increase in the share of the top $1 \%$ in the distribution of revenue due to the extensive use of oil resources can also be explained with the presence of structural problems in the country's economy. The presence of a monopoly in key areas has led to the formation of a small group, which received very high returns in the process of stimulating the business activity with the entry of large amounts of oil money into the economy.

The highest value of elasticity is attributed to the income of the top $10 \%$. For this group of population, the growth rate of income has been relatively high during the period of the

\footnotetext{
${ }^{6}$ Aspiration to seize the economic rent gained from the use of natural resources through dynamic interaction through fiscal processes that provide open access to investment resources social groups having strong positions in conditions legal and political institutions' weaknesses the Researchers have called Voracity Effect (See: Aaron and et., 1999, p. 22-46).
} 


\section{Articles}

rise in oil revenues. Adverse reaction to the situation in this group has also been shown in the context of the decline in funds. The share of the upper class in total revenue growth has repeatedly exceeded the share of this category in the total population (Table 3).

Consequently, changes in the latter decile have played a leading role in the overall dynamics of revenue distribution. The rapid increase in the use of oil revenue has resulted in the formation of a very high share of this group. According to this indicator, Azerbaijan is ahead of the countries of the region. (At present this indicator in Azerbaijan corresponds to the respective index of South Africa). At the same time, this is mainly due to the top $1 \%$. The ratio between the first and last deciles, as well as the top $1 \%$ and the top $10 \%$ (41:50) is very high in Azerbaijan. According to this indicator, our country can be compared with Qatar (World Inequality Lab, 2018).

The relatively high rate of growth on the lowest $10 \%$ is related to the wider use of oil revenues in the Republic of Azerbaijan to improve the welfare of socially vulnerable segments of the population. In this respect social benefits to low-income families were increased, pension payments were supported from the state budget, and programs were implemented to increase employment, including for lowest-income segments of the population. In 2003-2017, the income of that group increased more than 3.6 times in physical terms. From 2005 to 2017 the problem of extreme poverty reduction in the country was solved. The share of the population with
Impact of Oil Revenue Spending on Income Distribution: the Case of Azerbaijan

incomes below the official poverty line fell from $42.8 \%$ to $4.8 \%$. In poor families, wellbeing has improved significantly. On the other hand, the income of the first decile is stillsensitive to the dynamics of oil revenue. With the decline in oil revenues spent in 20142017 , the rate of physical growth in incomes in that group declined sharply. In general, the share of the first decile in population incomes is still relatively high compared to international results.

Another key feature of the population income dynamics in the Republic of Azerbaijan is the low level of growth of the share of the middle $40 \%$ group. In the course of the oil boom, the level of this indicator has declined sharply. This is due to the fact that income growth rates for the same group are weaker than the other groups. The value of the elasticity coefficient of the growth of the middle class incomes in relation to the increase in oil revenues used is considerably lower than that of other groups. The reaction of the change in the physical volume of revenues in this group to the decline in oil revenues was also relatively weak. In other words, the income of the middle class showed lower dependence on the dynamics of oil revenues used compared to other groups. It also influences the ratio between the income of the middle and lower classes under the use of oil money in the economy, and has played a role in the formation of the relatively high proportion of the first decile income in the study period. ${ }^{7}$

${ }^{7}$ Corresponding estimates allow us to say that this indicator for Azerbaijan is much lower than in neighboring countries. Noting that the comparisons are not sufficiently correct in this case, we would like to note that the relevant indicator of Azerbaijan at this time corresponds to the share of the middle class in the United Arab Emirates - ( See: World Inequality Lab, 2008). 


\section{Articles}

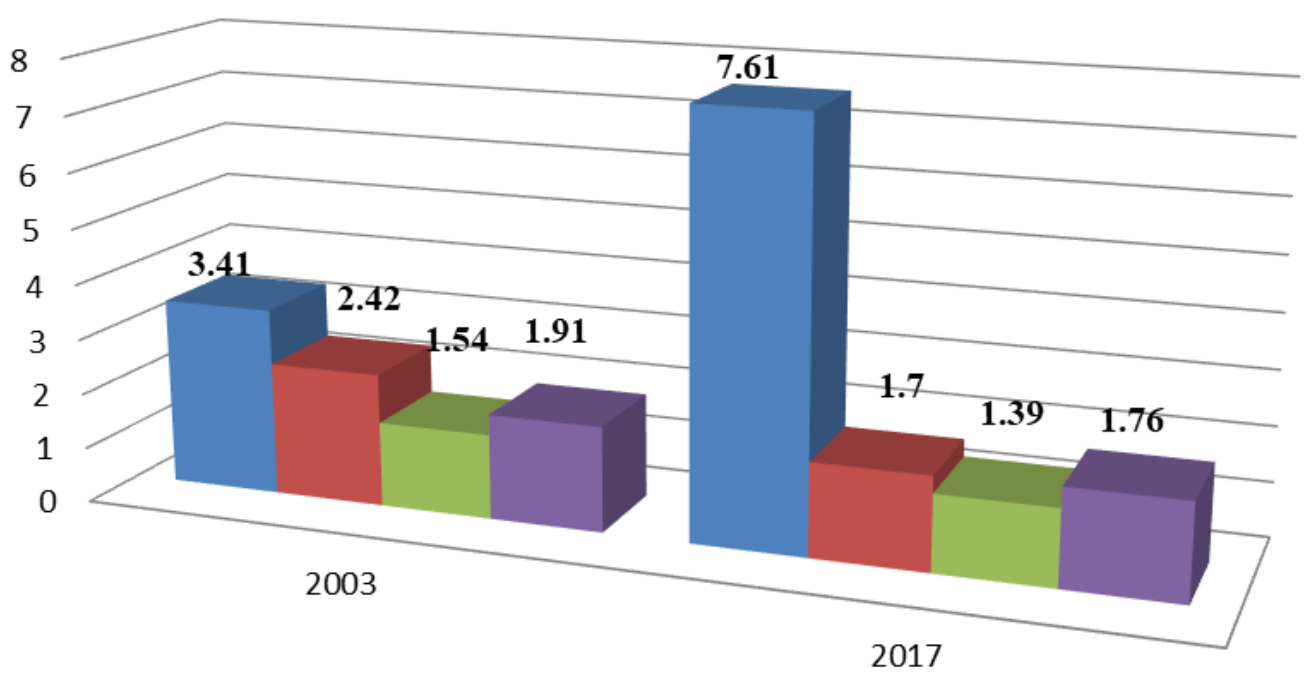

Coefficient of lags behind from the top 10\% Coefficient of ahead the bottom $10 \%$

Coefficient of ahead the bottom $50 \%$

- Cofficient of ahead the living wage

Figure 5. Relative indicators per capita income on the middle $\mathbf{4 0} \%$ group

As can be seen from figure 5 , in the case of large use of oil revenues, in the middle $40 \%$ group the coefficient of advancing of income per capita is significantly reduced compared with relevant indicators on the lowest $10 \%$ and lowest $50 \%$ groups. On the contrary, the coefficient of laggard from the top $10 \%$ group sharply increased. In other words, the average level of income in the middle group has approached the income level of the lower group. And the income of the upper class is far from the same level. At the same time, in the course of this process, the average income per capita in the group of $40 \%$ declined slightly in relation to the indicator of the living wage officially determined in the country. From this point of view, the use of large amounts of oil revenues in the economy does not contribute significantly tothe formation of the middle class within the country.

The World Bank report shows that from 1995 to 2014, Azerbaijan's wealth has increased 3.8 times to USD 813,730 million. During this period, the share of oil and gas increased from $19 \%$ to $42 \%$ in this wealth. The share of human capital dropped from $20 \%$ to $14 \%$. This again demonstrates the need to pay more attention to human capital(World Bank, 2019a). The opportunities for increasing human capital as one of the key factors in reducing overall inequality, positively affecting the average $40 \%$ and low $50 \%$ income, with increased use of oil revenues, have not been fully exploited.The average annual growth rate of spending for education and healthcare in 2003-2017 was 2.6 and 1.4 times lower than the average annual public spending. As a result, the share of education in the state budget declined from $19.2 \%$ to $8.7 \%$ and the share of healthcare from $4.5 \%$ to 3.1 . During the period under review, progress in improving education indicators was less than in countries that have land borders with Azerbaijan. (Table 4). 
Table 4. Changes in the Index of Education by Countries in 2003-2017

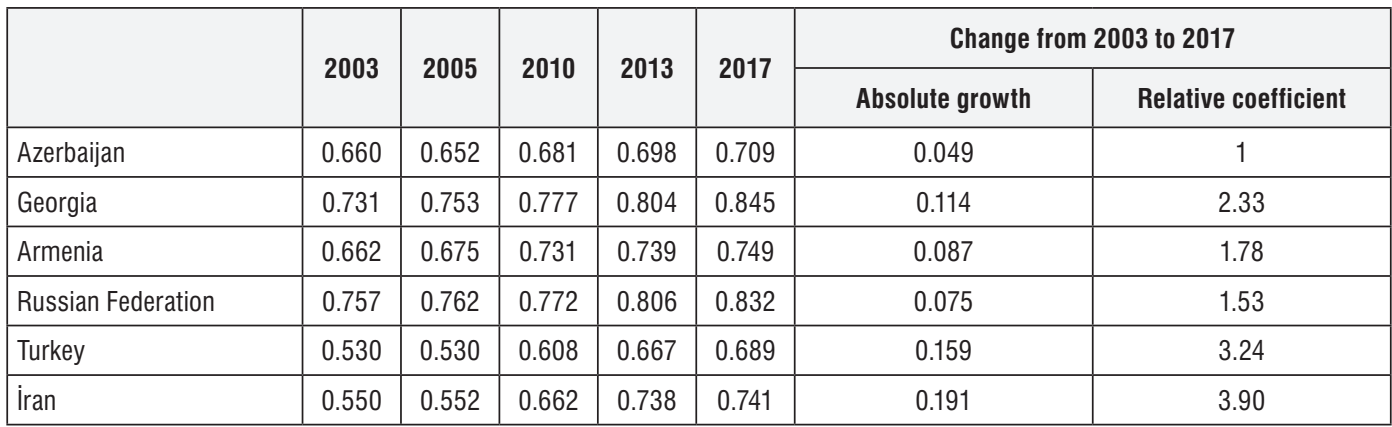

Source: UNDP, 2019

In the report "Human Capital Index" published by the World Bank for 2018, Azerbaijan holds middle ranks (65th) among 157 countries. The Strategic Roadmap of Azerbaijan stresses that Azerbaijan will be ensured at two levels:

1. Improving the quality of education at all stages for the formation and development of human capital;

2. Encouraging investing in continual development, research and improvement areas toensure that labor productivity is enhanced(SRNEPRA, 2016).

Under the condition of the sharp decline in oil revenues, the Gini coefficient has been decreasing slightly, but the inequality in income distribution is generally high.

This was also due to the active influence of the oil factor. As a result of the sharp decline in oil revenues, strong cuts in public investment, and a significant decline in overall

— 2017 - 2003

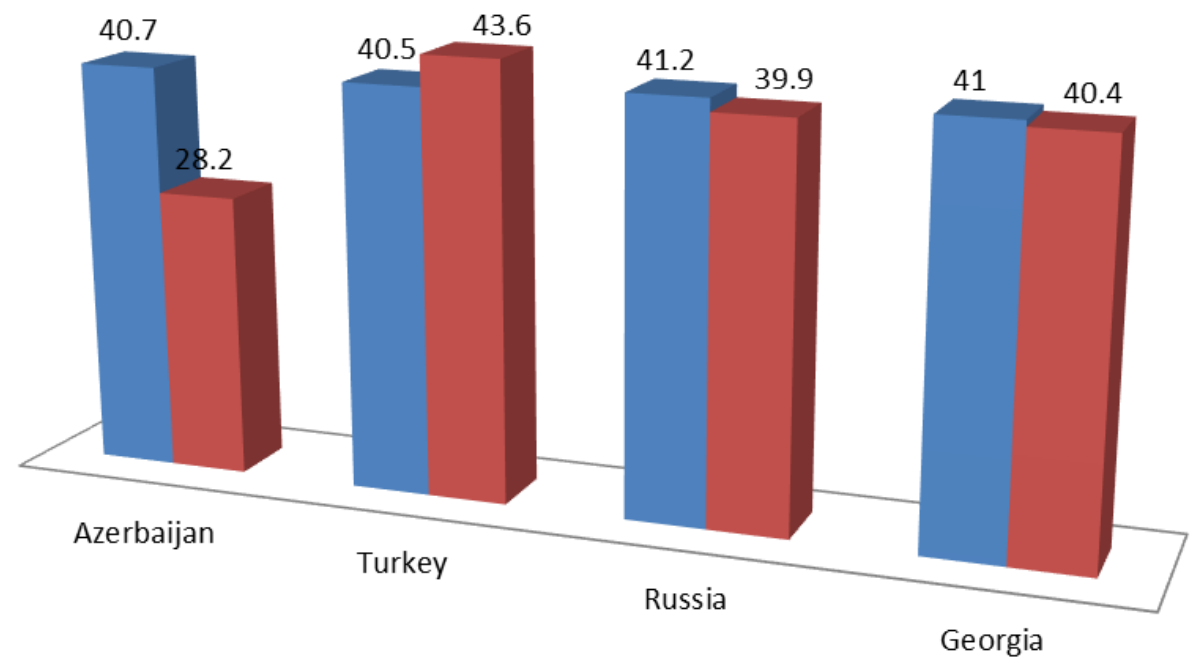

Figure 6. Value of the Gini Ratio on Income in 2003 and 2017 (\%)

Note: Calculated on the basis of national statistics data 


\section{Articles}

economic activityin the country, a decline in the high incomes generated by the abovementioned channels is observed. At the same time, there has been a decline in the number of employees with relatively high salaries in the oil and gas sector due to the decline in the oil market during the period under review and the decline in production in Azerbaijan. In this case, as can be seen from Table 3, incomes of the top $10 \%$ have declined and their share in population incomes has decreased significantly. In other groups, the value and share of income in nominal terms increased to some extent.

In general, it would not be appropriate to consider the decline in oil revenues used in Azerbaijan as a sustainable factor in reducing income inequality. Beginning in 2018, the use of oil revenue grows again. It is unlikely that this indicator will fall to the level of 2016-2017 in the near future. The main trend in this area is expected to increase or stabilize at lower rates. In other groups, the value and share of income in nominal terms increased to some extent.

Prior to the oil boom, income inequality in Azerbaijan was much lower than in neighboring countries. Subsequently, the value of the Gini coefficient due to the widespread use of oil revenues, was closer to the corresponding indicators for Russia, Turkey and Georgia (Figure 6).

The elimination of high inequality in the distribution of income which isgenerated by the widespread use of oil revenues is strategically linked to the large-scale diversification of the economy. This implies accelerating the development of both export-oriented and import-substituting industries in the non-oil sector of the economy. At the same time, it should be borne in mind that the fundamental reduction in the dependence of the
Azerbaijani economy on oil revenues through diversification can be completely resolved through the consistent implementation of long-term and comprehensive strategies.

\section{Conclusion}

In the early 2000s, in connection with the rapid growth of oil and gas production in Azerbaijan, the use of revenues from the sale of hydrocarbon resources for economic and social development has become an effective exogenous factor in the formation of population incomes and welfare indicators.

The increase in the volume of used oil revenues has accelerated the growth of nominal and real incomes, while increasing the level of inequality in the distribution of income in the context of an insufficient institutional capacity and structural problems in the economy.

The increase of oil money has a strong impact on income growth in the highestincome group, significant in the low-income group, and relatively weak in the middleincome group. Wherein, an increase in the overall level of inequality is happening due to the sharp increase of the share of the last decile, mainly the top $1 \%$ in incomes, almost stabilization of the share of the first decile, and the significant decline share of the middle group.

The use of a large amount of oil revenues has led to a sharp reduction in the poverty level, however at the same time oil revenues have not opened up wide enough opportunities for the formation of a wide, prosperous middle class in society.

The widespread use of oil revenue for economic and social development has resulted in the Republic of Azerbaijan joining the ranks of countries in the region with a relatively large income inequality. The rise in 


\section{Articles}

income inequality will further increase wealth inequality in the future.

The significant reduction in inequality is associated with the sharp weakening of the population's income dependence on the oil factor and, more precisely, with the weakening limitation of the role of direct and indirect sources of income from oil and gas sales. This is possible under the conditions of diversification of the economy and sustainable development of the whole economy.

Given that this strategy can only be calculated in the long run, there is a growing need to focus on improving the quality of institutions and accelerating reforms in this area as an important tool to reduce inequality in the short and medium term in the context of a widespread use of oil revenues.

Improving management in the use of oil resources for economic and social development purposes has the potential to play an important role in reducing income inequality. In terms of reducing income inequality, improving the use of oil revenues in certain directions also has particular importance. From this point of view, it is necessary to increase investment in the development of skills and education as a key factor in reducing the inequality in the modern world. Human capital plays a crucial role in increasing labor productivity, sustaining economic growth, improving the competitiveness of the manufacturing and service sectors and integrating the country in the global markets. In order to achieve this, it is necessary to improve the quality of education at all levels, ensure continuity in developing employee skills and knowledge, adapt qualified personnel training to the requirements of the labor market, stimulate companies to invest in researches and improvement areas and officially use the existing human capital.
Impact of Oil Revenue Spending on Income Distribution:

the Case of Azerbaijan

Also, priority should be given to sectors of the economy with high labor income when using oil funds to stimulate the diversification of the economy.

\section{References}

Aaron, T., Philipv, R. L., 1999.The Voracity Effect.The American Economic ReviewVol. 89, No. 1

Agnani, B., Izay,A., 2008. Growth in an oil abundant economy: The case of Venezuela. August, (n/b)

Albertina, R.D., 2013. Expenditure Policy in Angola: Impact on Economic Development and Inequality.152211011Lisbon,

Alakbarov, U., 2019.Fundamentals of inclusive development management. Baku -2019.

Anamaría, P., 2009. Oil Booms and Their Impact Through Fiscal Policy. Department of Economics and Graduate School of Business Stanford University May 25, (n/b-2)

Auty, R., M., 2001.The political economy of resource-driven growth. EuropeanEconomicReview 02/2001; 45(46):839-846. DOI: 10.1016/S00142921(01)00126-X.

Benhua, Y., Yewfoong, L., 2001. Resource booms and economic development: the time seriesdynamics for 17 oil-rich countries. Applied Economics Letters 10/2008.

CBAR., 2018.Key Macroeconomiclndicators. Central Bank of the Azerbaijan Republic. [Cited 11March 2020]http://en.cbar.az/ Ipages/statistics/key-macroeconomicindicators.

Dreger,C.,Rahmani, T., 2014.The Impact of Oil Revenues on the Iranian Economy and the Gulf StatesIZADPNo.8079.

Leamer, Edward E. \& Maul, Hugo \& Rodriguez, Sergio \& Schott, Peter K., 1999. "Does natural resource abundance increase Latin American income inequality?," Journal of 


\section{Articles}

Development Economics, Elsevier, vol. 59(1), pages 3-42, June.

Fasano-Filo, U., 2000.Review of the Experience with Oil Stabilization and Savings Funds in Selected Countries.Working Paper No. $00 / 112$

Gulaliyev, M., Aga, A., Azizov, A., Kazimov, F., Mir-Babayev, R., 2018. Assessing the degree of inequality in the distribution of national income and its macroeconomic consequences in Azerbaijan. Amazonia Investiga / Vol. 7 Núm. 17: 85- 108/ Noviembre - diciembre. p.85-108.

Gulaliyev, M.,Kazimov, F.,Abasova, S.,Gurbanova, T.,Mammadova, G.,Tagiyeva, N., 2020. Macroeconomic effects of income inequality: Azerbaijan case/Revista ESPACIOS. Vol. 41 (№ 24) 2020

Gylfason, T., Zoega, G., 2002. "Inequality and Economic Growth: Do Natural Resources Matter?," (also available at https://www. cesifo.org/DocDL/712.pdf)

Gylfason, T., Zoega, G., 2001. Natural Resources and Economic Growth: The Role of Investment. (also available at https:// notendur.hi.is/gylfason/_borders/pdf/ natinvest31.pdf)

Gronwald, M., Mayr, J., Orazbayev, S., 2009. Estimating the effects of oil price shocks on the Kazakh economy. Ifo Working Paper No. $81(\mathrm{n} / \mathrm{b})$

Idrisov, G., Kazakova, M., Polbin, A., 2015.A theoretical interpretation of the oil prices impact on economic growth in contemporary Russia. Russian Journal of Economics

IMF. (2013). Country Report No. 13/291(September 2013) Republic of Kazakhstan selected issues International Monetary Fund Washington, D.C.

Indermit, S., Ivailo, I., Willem, V.,Donato, D., 2014.Diversifieddevelopment making the most of natural resources in Eurasia.International Bank for Reconstruction and Development /
The World Bank1818 H Street NW Washington, DC 20433.

Indermit S., Gill, Ivailo, I., Willem van Eeghen, Donato De R., 2014. Diversified

Development. Making the most of natural resources in Eurasia. (also available at https://openknowledge.worldbank.org/ handle/10986/17193)

Junko, K., Vitali K., 2008. Impact of Government Expenditure onGrowth: The Case of AzerbaijanWP/08/115(n/b) 17

Lederman, D.,William F., 2007. Natural Resources: Neither Curse norDestiny (Washington, DC: The World Bank)

(also available at https://openknowledge. worldbank.org/bitstream/handle/10986/7183/ 378930LAC0Natu101OFFICIALOUSE0ONLY1. pdf?)

Lewis, J.D., 1995. "Indonesia's Industrial and Trade Policy During and After the Oil Boom," Papers 491, Harvard - Institute for International Development.

Lukke, E. A., Johann C. R., Faris S., Mauricio M., 2006.Natural Gas and Inequality in Bolivia after Nationalization/Institute forAdvanced Development StudiesDevelopment Research Working Paper Series No. 05/2006

Mehrara, M., 2008. The asymmetric relationship between oil revenues and economicactivities: The case of oil-exporting countries. Energy Policy, 36(3).

Merlevede B., Schoors.K, Aarle B., 2004. "Russia from Bust to Boom: Oil, Politics or the Ruble?," William Davidson Institute Working Papers Series 2004-722, William Davidson Institute at the University of Michigan.

Mgbame C., Donwa P., Onyeokweni O., 2015. Impact of oil price volatility on Economic growth: Conceptual perspective.International Journal of Multidisciplinary Research and Development. Volume: 2, Issue: 9, 8085. Sep 2015.(also available at http:// 


\section{Articles}

www.allsubjectjournal.com/archives/2015/ vol2issue9/2-7-127.pdf)

Roos M., 2006. How Mineral Rich States Can Reduce Inequality?.Initiative for Policy Dialogue Working Paper.(also available athttp://policydialogue.org/files/publications/ papers/Ch09.pdf

Mohammad, A., 2009. Oil Resource Abundance, Economic Growth and Income Distribution in Iran. No 21500069, EcoMod2009 from EcoMod. Date: 2009-06-01https:// ecomod.net/sites/default/files/documentconference/ecomod2009/990.pdf

Oviasuyi, P. O., Omoregie, A. E. (2016).Oil revenue and income inequality in Nigeria. International Journal of E-Government \& E-Business Research, Vol. 1, Issue 1, Jul-Dec, 2016, pp 37-50

PoA., 2019.President of the Republic of Azerbaijan.Speech by IlhamAliyev at the meeting economic area under the President of Azerbaijan.[Cited 22 October 2019]https:// en.president.az/articles/34463

Sabiroglu, I.,Bashirli, S., Qasimli, F., 2011. Creating a Favourable Deployment Mechanism of Oil and Gas Revenues with Regard to Volatile Oil Prices: The Case of Azerbaijan. Transition Studies Review 18(1):179-199 . September 2011. DOI: 10.1007/s11300-0110183-5

Sachs, J., Warner, A., 1995. Natural resource abundance andeconomic growth, NBER Working Paper Series https://www.nber.org/ system/files/working_papers/w5398/w5398. pdf

Sachs, J., Warner, A., 1999. The big push, natural resource boomsand growth.https:// www.earth.columbia.edu/sitefiles/file/about/ director/pubs/JnlofDevtEcon1999.pdf

SCCRA.,2019.State Customs Committee of the Republic of Azerbaijan.[Cited 25 October 2020].https://customs.gov.az/az/faydali/
Impact of Oil Revenue Spending on Income Distribution:

the Case of Azerbaijan

gomruk-statistikasi/xarici-ticaretin-veziyyetihaqqinda/

SRNEPRA., 2016.Strategic Roadmap for National Economy Perspective of the Republic of Azerbaijan. Baku, 06 December 2016.

SSCAR., 2015.Statistical Yearbook of Azerbaijan 2015, State Statistical Committee of Azerbaijan Republic. Baku 2015.

SSCAR., 2018.Statistical Yearbook of Azerbaijan 2018, State Statistical Committee of Azerbaijan Republic.Baku 2018

SSCAR., 2019. State Statistical Committee of Azerbaijan Republic.[Cited 11 October 2020] https://www.stat.gov.az/?lang=en

SOFAZ., 2017.Annual Reports, 2005-2017. State Oil Fund of the Azerbaijan.

SOFAZ., 2019.State Oil Fund of the Republic of Azerbaijan.[Cited 21 December 2020]. https://www.oilfund.az/report-and-statistics/ report-archive.

Torvik, R., 2002. "Natural resources, rent seeking and welfare," Journal of Development Economics, Elsevier, vol. 67(2), pages 455-470, April.

UNDP.,2018. Human Development Indices and Indicators 2018 Statistical(also available at http://hdr.undp.org/sites/default/files/2018_ human_development_statistical_update.pdf.)

UNDP., 2019. Human Development Data (1990-2017).[Cited 21 October 2019]. http:// hdr.undp.org/en/data. Cited 21 Oct 2019

World Bank., 2019a.World Development Indicators, 2000-2018.[Cited 20 December 2019]http://data.worldbank.org/datacatalog/world-development-indicators.

World Bank., 2019b.South Caucasus in Motion.Poverty and Equity Global Practice Europe and Central Asia. January 2019

World Bank., 2018.The Changing Wealth of Nations 2018. Building a Sustainable Future.

World Bank., 2015. "Country Partnership Framework for Azerbaijan for the Period 
Articles

FY16-FY20." Report 95860- AZ (June 3), South Caucasus Country Management Unit, Europe and Central Asia Region, World Bank, Washington, DC.

World Bank., 2016. "Europe and Central Asia: Macro Poverty Outlook 2016." World Bank, Washington, DC.
World Inequality Lab., 2018.World Inequality Report 2018.(also available at https:// wir2018.wid.world/)

World Economic Forum., 2019.The Global Competitiveness Report 2019.(also available athttp://www3.weforum.org/docs/WEF TheGlobalCompetitivenessReport2019.pdf) 